\title{
Gangguan Kelenjar Keringat Apokrin: Bromhidrosis dan Kromhidrosis
}

\author{
${ }^{1}$ Stanley Setiawan, ${ }^{2}$ Pieter L. Suling \\ ${ }^{1}$ Bagian Ilmu Kesehatan Kulit dan Kelamin Fakultas Kedokteran Universitas Kristen \\ Indonesia Jakarta \\ ${ }^{2}$ Bagian/KSM Ilmu Kesehatan Kulit dan Kelamin Fakultas Kedokteran Universitas Sam \\ Ratulangi/RSUP Prof. Dr. R. D. Kandou Manado \\ Email: stan_setiawan@yahoo.com
}

\begin{abstract}
Apocrine gland is one of the sweat glands in humans. This gland is considered as a gland that causes odor. Primary abnormalities in the apocrine glands are bromhidrosis and chromhidrosis. Bromhidrosis is a state of abnormal or offensive body odor due to the secretion of apocrine sweat glands lies in the armpit, scalp, soles of the feet, fingers, and genital. Chromhidrois is a fairly rare condition, characterized by the secretion of colored sweat from the pigmented apocrine glands that usually present in the armpits and face. In general, management of bromhidrosis and chromhidrosis including non-medicamentous, medicamentous, and surgery shows satisfying result.
\end{abstract}

Keywords: apocrine bromhidrosis and apocrine chromhidrosis

\begin{abstract}
Abstrak: Kelenjar apokrin merupakan salah satu kelenjar keringat pada manusia, dan kelenjar ini dianggap sebagai kelenjar yang menyebabkan bau badan. Kelainan primer pada kelenjar apokrin yaitu apokrin bromhidrosis dan apokrin kromhidrosis. Bromhidrosis adalah keadaan bau badan seseorang yang berlebihan dari normal akibat sekresi kelenjar keringat apokrin yang terletak di ketiak, kulit kepala, telapak kaki, sela-sela jari, dan genital. Kromhidrohis merupakan keadaan yang cukup jarang ditemukan, ditandai dengan sekresi keringat dari kelenjar apokrin yang berwarna, biasanya terdapat pada ketiak dan wajah. Secara umum penatalaksanaan bromhidrosis dan apokrin kromhidrosis meliputi nonmedikamentosa, medikamentosa, dan pembedahan memperlihatkan hasil yang memuaskan.
\end{abstract}

Kata kunci: apokrin bromhidrosis, apokrin kromhidrosis

Kelenjar apokrin merupakan salah satu kelenjar keringat pada manusia yang terdapat pada kepala, aksila, anogenital, kelopak mata, meatus acusticus externus (external auditory meatus), dan kelenjar mammae. Kelenjar apokrin dapat juga ditemukan pada wajah dan perut. ${ }^{1,2}$ Fungsi sebenarnya dari kelenjar apokrin tidak begitu jelas, dan kelenjar ini dianggap sebagai kelenjar yang menyebabkan bau.

Kelainan primer pada kelenjar apokrin yaitu apokrin bromhidrosis dan apokrin kromhidrosis. ${ }^{4}$ Bromhidrosis adalah keadaan bau badan seseorang yang berlebihan dari normal akibat sekresi kelenjar keringat apokrin yang terletak di ketiak, kulit kepala, telapak kaki, sela-sela jari, dan genital. Pada keadaan ini, kulit menjadi basah dan lengket serta menimbulkan bau yang tidak nyaman sebagai hasil degradasi produk kelenjar apokrin oleh mikroba kulit. ${ }^{5}$ Kromhidrohis merupakan keadaan yang cukup jarang ditemukan, ditandai dengan sekresi keringat dari kelenjar apokrin yang berwarna, biasanya terdapat pada ketiak dan wajah. Selain keringat yang berwarna, kromhidrosis juga ditandai dengan sensasi gatal dan panas.

Tulisan ini mengulas mengenai penyakit primer dari kelenjar apokrin, yaitu bromhidrosis dan kromhidrosis. 


\section{Kelenjar Apokrin}

Istilah apokrin berasal dari bahasa Yunani apo yang berarti pergi dan krinein yang berarti untuk memisahkan. Kelenjar ini merupakan bagian dari adneksa kulit yang terletak di epidermis dan berkembang sebagai bagian dari kelenjar pilosebasea pada bulan ke 4 dan 5 dari kehidupan janin. $^{6}$

Kelenjar apokrin tidak berfungsi sampai pada masa pubertas; oleh karena itu perkembangannya dikaitkan dengan faktor hormonal yang mengalami perubahan pada masa pubertas. $^{2}$

\section{Anatomi dan Fisiologi Kelenjar Apokrin}

Kelenjar apokrin terdiri dari tiga komponen, yaitu: 1) Duktus intraepithelial; 2) Duktus intradermal; dan 3) Coiled gland atau kelenjar yang melingkar pada dermis atau perbatasan dermis dan lemak subkutan yang mengandung bagian sekretori (Gambar 1A). ${ }^{2}$ Modus sekresi ialah dekapitasi yaitu proses dimana bagian apikal dari sitopik sekretori menutup dan masuk ke dalam lumen kelenjar (Gambar 1B). ${ }^{1}$ Bentuk kelenjar apokrin lebih besar dari kelenjar ekrin.,3
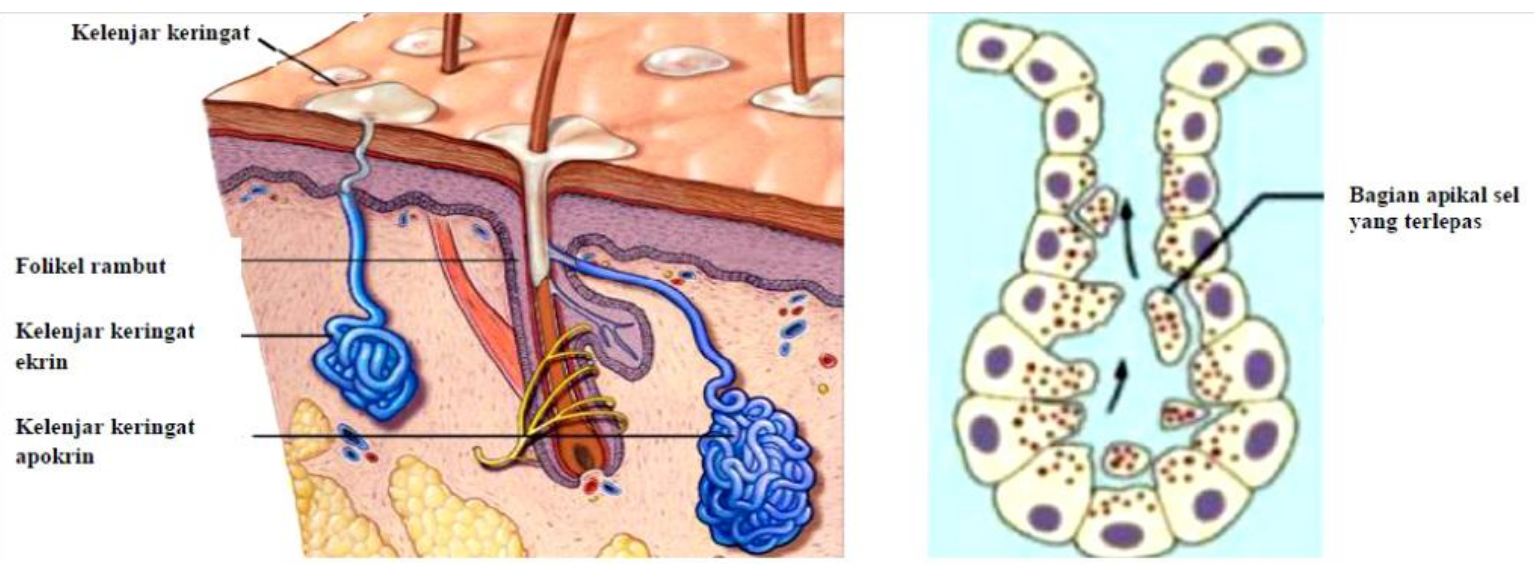

Gambar 1. A, Bagan kulit manusia yang memperlihatkan kelenjar keringat ekrin dan apokrin. B, Kelenjar keringat apokrin; tampak bagian apikal sel yang terlepas. Sumber: Schaller dan Plewig, $2012 .^{1}$

\section{Komposisi Sekret Kelenjar Apokrin}

Sekret kelenjar apokrin utamanya mengandung sialomusin yang lebih kental dan diproduksi dalam jumlah yang lebih sedikit daripada kelenjar ekrin. Kelenjar apokrin mengeluarkan sejumlah kecil cairan berminyak. ${ }^{3,6}$ Saat pertama kali disekresikan, sekret kelenjar apokrin manusia seperti susu, kental, dan tidak berbau saat mencapai permukaan kulit. Dekomposisi bakteri bertanggung jawab atas produksi senyawa odiferous. Secara khusus, aminoacylase corynebacteria bertanggung jawab atas produksi asam 3-methyl-2hexenoic dan 3-hydroxy-3-methylhexenoic. Produksi metabolit ini berada di bawah kendali genetik gen $\mathrm{ABCC} 11 .{ }^{4,7}$

\section{Kegunaan Kelenjar Apokrin}

Kegunaan kelenjar apokrin antara lain sebagai odoriferous sexual, territorial markers, dan sinyal penanda. Kelenjar ini juga berperan dalam meningkatkan resistensi friksional dan sensibilitas taktil, serta meningkatkan evaporasi panas pada individu tertentu. ${ }^{4}$ Kelenjar ini merespon rangsangan emosi hanya setelah pubertas, dan dapat distimulasi oleh epinefrin dan norepinefrin baik secara lokal atau sistemik. Hasil studi menunjukkan bahwa kelenjar apokrin dikendalikan terutama oleh agonis adrenergik, walaupun beberapa kontrol kolinergik juga telah dilaporkan. ${ }^{4,5}$

Gangguan kelenjar keringat apokrin yang dibahas dalam tulisan ini ialah bromhidrosis dan kromhidrosis. 


\section{Bromhidrosis}

Bromhidrosis atau disebut juga osmidrosis adalah keadaan bau badan seseorang berlebihan dari yang normal akibat sekresi kelenjar keringat apokrin., ${ }^{4,5}$

Bau badan biasanya berkembang setelah masa pubertas, umumnya laki-laki lebih sering dari perempuan. Onset penyakit sering pada populasi Afrika-Amerika dan Eropa; jarang pada Asia Timur, Tiongkok, dan Korea. $^{7-9}$ Tidak terdapat predileksi geografik, meskipun musim panas atau iklim panas dapat memperparah penyakit ini. Kebersihan pribadi yang buruk juga bisa menjadi faktor pencetus. ${ }^{4,10}$

\section{Etiopatogenesis Bromhidrosis}

Sekresi apokrin bertanggung jawab terhadap produksi bau, terutama melalui kerja bakteri pada komponennya. Steroid yang tidak berbau disebut feromon berkontribusi terhadap osmidrosis. Pada bromhidrosis, bakteri yang berperan terutama korinebakterium aerobik. Bakteri pada sekresi apokrin menghasilkan amonia dan asam lemak rantai pendek kemudian asam ini dibawa ke permukaan kulit oleh dua jenis protein pengikat yaitu ASOB1 dan ASOB2. ${ }^{4,9}$ Peran hiperhidrosis pada bromhidrosis masih belum jelas diketahui., ${ }^{4,9}$

\section{Gejala Klinis Bromhidrosis}

Gejala utama yang dikeluhkan yaitu bau badan tidak sedap, umumnya berasal dari ketiak, walaupun terkadang area genital dan telapak tangan juga terlibat. Pada bromhidrosis tidak didapatkan lesi pada kulit. ${ }^{4}$

\section{Diagnosis Banding Bromhidrosis}

Bromhidrosis didiagnosis banding dengan: ekrin bromhidrosis (fish odor syndrome, phenylketonuria, sweaty feet syndrome, odor of cat syndrome, isovaleric academia, hypermethioninemia, food, drug, toxin ingestion), liver failure (fetor hepaticus), renal failure, nasal foreign body in children, poor hygiene, olfactory hallucinations, dan body dysmorphic disorder. ${ }^{4,7}$

\section{Penatalaksanaan Bromhidrosis}

Secara umum penatalaksanaan bromhidrosis terdiri dari beberapa hal, yaitu: rutin membersihkan ketiak dan mengurangi bulu ketiak, mengganti pakaian terutama saat berkeringat, sabun antibakterial/antibakterial topikal, menghindari beberapa jenis makanan penyebab bau badan (bawang putih dan daging merah), deodoran dan antiperspiran, antibiotik, antiseptik dan antikolinergik. $^{10-12}$

Penatalaksanaan tanpa pembedahan ialah dengan menggunakan toksin botulinum A dan laser frequency-doubled $Q$ switched Nd:YAG. ${ }^{13,14}$ Dapat juga dilakukan tindakan pembedahan dengan pengangkatan kelenjar apokrin, tumescent liposuction disertai kuretase, upper thoracic sympathectomy, pengangkatan jaringan subkutan disertai ablasi laser $\mathrm{CO} 2$, aspirasi bedah ultrasonik, dan suction-assisted cartilage shaver. ${ }^{4,7}$

\section{Prognosis Bromhidrosis}

Apokrin bromhidrosis merupakan kondisi kronis yang terjadi terus menerus. Pasien dengan apokrin bromhidrosis sering merasa rendah diri dan malu dengan kondisinya yang dapat menyebabkan gangguan fungsi psikososial. ${ }^{4,10}$

\section{Kromhidrosis}

Kromhidrosis adalah kondisi langka yang ditandai dengan sekresi keringat apokrin berwarna. Pada tahun 1954 Shelley dan Hurley menggambarkan entitas ini dan menghubungkannya dengan peningkatan jumlah butiran lipofusin dalam kelenjar apokrin. ${ }^{4,7,15}$

Kromhidrosis jarang terjadi. Prevalensi di seluruh dunia tidak diketahui, namun biasanya terjadi pada masa puber. ${ }^{16}$ Penyakit ini terus berlanjut sepanjang hidup, dan membaik di usia lanjut. ${ }^{4}$ Rasio kejadian pada laki-laki maupun perempuan tidak diketahui secara jelas. Pengaruh faktor geografik belum pernah dijelaskan. ${ }^{16}$

Pigmen yang bertanggung jawab untuk menyebabkan kromhidrosis apokrin ialah lipofusin yang diproduksi di sel-sel sekretori apokrin dan diekskresikan ke perm- 
kaan kulit. Dalam kromhidrosis apokrin, butiran lipofusin berada dalam keadaan oksidasi yang lebih tinggi; dengan demikian memberikan berbagai warna pigmen, seperti kuning, hijau, biru, atau hitam. Keadaan oksidasi yang lebih tinggi menghasilkan warna yang lebih gelap. ${ }^{17}$

\section{Gejala Klinis Kromhidrosis}

Terdapat tiga subtipe yang dikemukakan oleh Cilliers and the Beer, yaitu: kromhidrosis ekrin sejati, pseudo-eccrine kromhidrosis, dan kromhidrosis apokrin.

Kromhidrosis apokrin tampak setelah pubertas, biasanya terbatas pada wajah dan aksila, jarang pada areola. Pada pasien akan tampak pewarnaan kuning, biru, hijau, dan biru-hitam pada pakaian. Kromhidrosis pseudo-eccrine terjadi ketika keringat yang tidak berwarna menjadi berwarna saat mencapai kulit karena reaksi dengan produk bakteri kromogenik eksogen, bahan kimia, cat, dan pewarna. Kromhidrosis ekrin sejati adalah kelainan umum yang terutama disebabkan oleh pewarnaan keringat ekrin yang jernih oleh pewarna, pigmen, atau logam. Pemicu keringat berwarna biasanya emosional atau rangsangan fisik. $^{17,18}$

\section{Diagnosis Banding Kromhidrosis}

Uji khusus yang dapat dilakukan ialah pemeriksaan lampu Wood, tes laboratorium, dan pemeriksaan histopatologik., Sebagai diagnosis banding, kromhidrosis apokrin harus dibedakan dari: quinine ingestion, blue sweat with copper exposure, extrinsic dyes, paints, alkaptonuria (okronosis)' hiperbilirubinemia' hematohidrosis (bleeding diathesis), chromogenic bacteria (spesies korinebakterium), dan pseudomonas. ${ }^{4,7}$

\section{Penatalaksanaan Kromhidrosis}

Toksin Botulinum tipe A telah dilaporkan berhasil pada pasien dengan kromhidrosis di daerah wajah. Demikian pula laporan kasus telah menunjukkan kemanjuran capsaicin pada kromhidrosis di daerah wajah. ${ }^{4,19}$

\section{Prognosis Kromhidrosis}

Kromhidrosis ialah penyakit kronis dan membaik di usia tua karena aktivitas kelenjar apokrin berkurang. Morbiditas terkait penyakit ialah akibat disfungsi psikososial yang dialami oleh individu yang terkena. ${ }^{4,16}$

\section{SIMPULAN}

Penyakit primer kelenjar apokrin yaitu bromhidrosis dan kromhidrosis merupakan salah satu masalah kesehatan yang dapat mengganggu kehidupan psikososial seseorang, yaitu menimbulkan rasa rendah diri.

Kemajuan dalam penatalaksanaan kedua jenis penyakit primer kelenajr apokrin ini telah memberikan peningkatan kepuasan pasien setelah dilakukan terapi.

Pemahaman patogenesis bromhidrosis dan kromhidrosis dapat membantu dalam penatalaksanaan kedua gangguan tersebut.

\section{DAFTAR PUSTAKA}

1. Schaller M, Plewig G. Structure and function of eccrine, apocrine and sebaceous glands. In: Bolognia JL, Jorizzo JL, Schaffer JV, Callen JP, Cerroni L, Heymann WR et al, editors. Dermatology (3rd ed). New York: Elsevier Saunders, 2012; p. 539-44.

2. Mauro TM. Biology of eccrine and apocrine glands. In: Wolff K, Goldsmith LA, Katz SI, Gilchrest BA, Paller AS, Leffell DJ, editors. Fitzpatrick's Dermatology in General Medicine (8th ed). New York: Mc Graw Hill Inc, 2012; p. 929-36.

3. James WD, Berger TG, Elston DM, editors. Skin: basic structure and function. In: Andrews' Diseases of the Skin Clinical Dermatology (12th ed). Pennsylvania: Saunders Elsevier, 2016; p. 1-10.

4. Zouboulis CC, Tsatsou F. Disorders of the apocrine sweat glands. In : Wolff K, Goldsmith LA, Katz SI, Gilchrest BA, Paller AS, Leffell DJ, editors. Fitzpatrick's Dermatology in General Medicine (8th ed). New York: Mc Graw Hill Inc, 2012; p. 947-59.

5. Widaty S, Sebono H, Nilasari H, Listiawan Y, Siswati AS, Triwahyudi D, et al. Panduan Praktik Klinis Dokter Spesialis Kulit dan Kelamin di 
Indonesia. Jakarta: PERDOSKI, 2017; p. 260-2.

6. McGrath JA, Uitto J. Structure and function of the skin. In: Griffiths CEM, Barker J, Bleiker T, Chalmers R, Creamer D, editors. Rook's Textbook of Dermatology (9th ed). West Sussex: Willey Blackwell, 2016; p. 2.1-3.0.

7. Coulson IH, Wilson NJE. Disorders of the sweat glands. In: Griffiths CEM, Barker J, Bleiker T, Chalmers R, Creamer D, editors. Rook's Textbook of Dermatology (9th ed). West Sussex: Willey Blackwell, 2016; p. 94.1-95.0.

8. James WD, Elston DM, Berger TG, editors. Diseases of the skin appendages. In: Andrews' Diseases of the Skin Clinical Dermatology (12 th ed). Pennsylvania: Saunders Elsevier, 2016; p. 741-82.

9. Miller JL. Diseases of the eccrine and apocrine sweat glands. In: Bolognia JL, Jorizzo JL, Schaffer JV, Callen JP, Cerroni L, Heymann WR et al, editors. Dermatology (4th ed). New York: Elsevier Saunders, 2018; p. 633-48

10. Siskawati Y, Bernadette I, Menaldi SL. Bau badan: patogenesis dan piñatalaksanaan. MDVI. 2014; 41(1):32-41.

11. Zirwas MJ, Moennich J. Antipespirant and deodorant allergy. J Clin Aesthet Dermatol. 2008;1(3):38-43.

12. Sitompul MO. Pengaruh makanan terhadap bau badan. 2015. [cited 2018 Jan 1].
Available from: http://e-journal.uajy. ac.id/8605/2/1BL01211.pdf

13. Glogau RG. Botulinum toxin. In : Wolff $K$, Goldsmith LA, Katz SI, Gilchrest BA, Paller AS, Leffell DJ, editors. Fitzpatrick's Dermatology in General Medicine (8th ed). New York: Mc Graw Hill Inc, 2012; p. 3053-61.

14. Schavelzon DE, Blugerman G, Chormyszyn A, Ponton JA, Lanfranchi LA, Martinez LA. Nonivasive treatment of axillary hyperhidrosis with $\mathrm{Nd}: \mathrm{YAG}$ laser. UpDate Plastic Surg. 2010;3(1): 29-32.

15. Hyunhee P. Review of Reported Cases of Kromhidrosis. [cited 2018 Jan 1]. Available from: http: //c.ymcdn.com/ sites/www.aocd.org/resource/resmgr/ja ocd/contents/volume30/30-05.pdf

16. Divya S. Bilateral facial kromhidrosis. JAAD. 2008:58(2):43.

17. Kenneth B, Hillary $O$. Axillary chromhidrosis: report of a case, review of the literature and treatment consi-derations. J Cosm Dermatol. 2010;9(4):318-20.

18. Perez TB, Zamora ME, Sanchez AB, Perez GYC, Polimon OI, Marinero ES, et al. Facial and axillary apocrine chromhidrosis. Dermatol Online J. 2012;18(3):221-5.

19. Seth L. Treatment of facial chromhidrosis with botulinum toxin type A. J Am Acad Dermatol. 2005;52(1):23-5. 